093

Received: July 12, 2009

Accepted: December 15, 2009
Macedonian Journal of Animal Science, Vol. 2, No. 2, pp. 143-148 (2012)

In print ISSN $1857-6907$

On line ISSN $1857-7709$

UDC: $637.62(496.5)$

Short communication

\title{
SHEEP WOOL PRODUCTION IN ALBANIA
}

\author{
Lumturi Papa ${ }^{1}$, Kristaq Kume ${ }^{2}$ \\ ${ }^{1}$ Animal Production Department, Agricultural University, Tirana, Albania \\ ${ }^{2}$ National Coordinator of Farm Animal Genetic Resources, Albania \\ lumturipapa@yahoo.com//kkume@abcom-al.com
}

\begin{abstract}
Actually, 1853 thousand sheep (1378 thousand milked sheep) are farmed in Albania. About $28 \%$ of the sheep population are the Tsygaia breed and its crossbreeds, $9.2 \%$ are the Merino breed and its crossbreeds, $12 \%$ are crossbreeds with other different imported breeds, local sheep named Rrecka present about $23 \%$ of the total sheep population and other autochthonous sheep breeds, like Ruda, Bardhoke, Shkodrane, Baca - located in the North and North East/West, and Syka of Mati, Lara of Polisit in central regions of Albania consist of $27.5 \%$. The imported breeds like Il de France, Chios, Awasi constitute about $0.3 \%$. The annual sheep wool production evaluates about 3.8 thousand ton. The structure of wool quality is $15.7 \%$ thin wool (merinos and their crosses), $27.1 \%$ half thin wool (Ruda, Tsigaia and their crosses) and $57.2 \%$ harsh wool (local breeds). The most part of wool produced by local sheep breeds is the coarse type. Only the wool of the Ruda sheep breed is of the half thin type, with 12-14 cm hair length and 3033 micron diameter of hair. Most of the Albanian wool is sold for export very cheaply, direct after shearing (not graded, not washed), some is simply incinerated. The farmers get a smaller part of their own wool carded. Afterwards it is hand spun and used for weaving or knitting. The coarse wool is used for kelims and carpets. The finer wool is used for knitting. In Albania it is a tradition carding, dyeing, hand spinning, weaving and knitting the wool to be done in small enterprises and home conditions. The elder generation knows how to handle the wool, but it is a dwindling tradition. Only a small and decreasing market for traditional wool products, such as traditional Albanian hats, kelims and knotted carpets exists. The support of farmers community to build up a market for modern wool production as small or medium scale enterprises and home production, then selling the products from specialized shops in bigger towns, and especially for the bigger enterprises, to end up with export is one of the important objectives of the Albanian National Action Plan for conservation and sustainable economic use of FAnGR. According to the National Action Plan to develop wool processing into finished end-products for sale, is necessary to look into small issues as sheep breeding at a farm level, development of breeding strategies, training farmers in sheep husbandry practices, grading the wool, scouring the wool, support to SMEs working with wool processing, training men/women in wool processing, design of products, marketing and bookkeeping.
\end{abstract}

Key words: sheep; wool processing; marketing

\section{ПРОИЗВОДСТВО НА ВОЛНА ВО АЛБАНИЈА}

Во Албанија во фармски услови се одгледуваат 1.853.000 овци (1.378.000 молзни овци). Околу 28\% од популацијата на овци отпаѓа на расата цигаја и расите добиени со нејзино вкрстување со други раси, 9,2\% отпаѓ на расата мерино и расите добиени со нејзино вкрстување со други раси, $12 \%$ отпаѓа на раси добиени со вкрстување со други различни увезени раси. Локалната овца наречена речка претставува околу $23 \%$ од вкупната популација на овци, а другите автохтони раси овци, како што се руда, бардока, шкодран, бака лоцирани на север и североисток/запад, и сика од Мати, лара од Полисит (централните региони на Албанија) се претставени со 27,5\%. Увезените раси како што се ил де франс, хиос, аваси се претставени со $0,3 \%$. Годишното производство на волна изнесува околу 3,8 илјади тони. Структурата на квалитетот на волната е 15,7 \% тенка волна (мерино и нејзините вкрстени раси), 27,1\% полутенка волна (руда, цигаја и нивните вкрстени раси) и 57,2\% груба волна (локалните раси). Најголемиот дел од волната произведена од локалните раси овци е од типот груба волна. Само волната од овцата руда е од типот полутенка волна, со должина на влакното 12-14 см и со дијаметар на влакното од 30-33 микрони. Најголем дел од волната во Албанија се извезува по многу ниска цена, веднаш по стрижењето (без претходно класирање, перење) или едноставно се изгорува. Фармерите имаат мала улога во преработката на волната. Тоа е рачна обработка и волната се употребува за ткаење или плетење. Грубата волна се користи за килими и теписи. Пофината волна 


\begin{abstract}
се користи за плетење. Во Албанија е традиција во мали претпријатија и во домашни услови да се врши чешлање, боење, рачно предење, ткаење и плетење на волната. Постарите генерации знаат како да ракуваат со волната, но тоа е традиција која постепено исчезнува. Постојат само мали пазари за традиционални волнени производи (традиционални албански капи, килими и чворести килими). Поддршката на фармерите за изградба на пазар за модерно производство на волна, како и на мали или средни претпријатија и производство во домашни услови, потоа продажба на производи во специјализирани продавници во поголемите градови, а специјално за поголеми претпријатија, вклучувајќи го извозот, е една од најважните цели на албанскиот Национален акционен план за заштита и одржлива економска употреба на FAnGR. Според Националниот акционен план неопходно е за преработка на волната во завршни продукти за продажба да се земаат предвид мали појдовни нешта - одгледување на овци на ниво на фарма, развој на стратегии за одгледување, обука на фармери, класирање на волната, перење на волната, поддршка на SMEs кои работат со преработка на волната, обука на мажи и жени за преработка на волната, дизајн на производите, маркетинг и матично книговодство.
\end{abstract}

Клучни зборови: овца; преработка на волна; маркетинг

\section{INTRODUCTION}

There is a very old tradition for sheep farming in Albania. Today's evolution and distribution of different sheep types and breeds is the result of development and change that took place over the past fifty years. Uncontrolled crossbreeding between different breeds, continuous changes of crossing schemes and its objectives have led to the existence of a great genetic variability within the sheep population. In particular this situation is emphasized in the sheep population located in the lowland that constitutes about $25-30 \%$. During the period from 1960 to 1990 that population was crossed with different types of the Merino breed. Today the meat sheep breed such as Ile de France is the most available. Local breed population of hilly areas of Albania and small populations of mountainous areas unless the Northern part of Albania constituting about $40 \%$ of the total ones, during 30 years were crosses with different types of the Tsigai and the Awasi breeds. Recently, the Chios breed imported by Greece is being used to crossings (Kume, K., 2006),

Actually, 1853 thousand sheep (1378 thousand milked sheep) are farmed in Albania. About $28 \%$ of the sheep population is the Tsygaia breed and its crossbreeds, $9.2 \%$ are the Merino breed and its crossbreeds, $12 \%$ are crossbreeds with other different imported breeds. The local sheep breed named Rrecka presents about $23 \%$ of the total sheep population. This breed is almost located in all mountainous and hilly areas of central and southern Albania. Other autochthonous sheep breeds, like Ruda, Bardhoke, Shkodrane, Baca, located in the Northern part of Albania, and Syka of Mati, Lara of Polisit, located in the central regions of Albania, consist of $27.5 \%$. The imported breeds like Il de France, Chios, Awasi constitute about
$0.3 \%$. The annual sheep wool production evaluates about 3.8 thousand ton (Statistical Yeardbook, 2003, 2008, MoAFPC).

\section{SHEEP POPULATION, FARM SIZES AND PRODUCTION}

According to the Statistical data of the Ministry of Agriculture, Food and Consumer's Protection, the population size and sheep production in Albania has not significant changes during the period from 1997 to 2008 (Tab. 1).

\section{Table 1}

Trend of size population and production*

\begin{tabular}{lccccc}
\hline \hline Item & 1997 & 2000 & 2003 & 2005 & 2008 \\
\hline Population sheep (1000) & 1982 & 1939 & 1903 & 1760 & 1883 \\
Milked sheep & 1453 & 1448 & 1441 & 1312 & 1438 \\
Milk production (000 tons) & 69 & 70 & 74 & 75 & 76 \\
Wool production (000 tons) & 3.2 & 3.4 & 3.4 & 3.5 & 3.8 \\
\hline \hline
\end{tabular}

*Statistical data - MoAFCP

Based in size populations of the local sheep breeds population (Tab. 2) it may be judged that, in general, these populations are not endangered, in not a risk status. The "Shkodrane" and the "Lara e Polisit" are at a critical level, only. As a matter of fact, as a consequence of the whole lack of programs for conservation and management the genetic erosion in these populations is significant. Among factors of the most negative influences is the use of uncontrolled rams for natural insemination. The insufficient level of knowledge of farmers, the lack of information and cooperation among 
them to exchange rams, the flocks of high inbreeding percentage are encountered (Kume, K. et al., 2003).

Table 2

Size and trend of the number of local sheep breed populations

\begin{tabular}{lcl}
\hline \hline Breed & Number & Trend in the number \\
\hline Recka & 287540 & $\boldsymbol{\nabla}$ Decreasing \\
Ruda & 87640 & - Stable \\
Bardhoke & 44150 & $\boldsymbol{\Delta}$ Increasing \\
Shkodrane & 524 & $\boldsymbol{\nabla}$ Decreasing \\
Bace & 18754 & - Stable \\
Lara e Matit & 3430 & $\boldsymbol{\Delta}$ Increasing \\
Lara e Polisit & 372 & $\boldsymbol{\nabla}$ Decreasing \\
\hline \hline
\end{tabular}

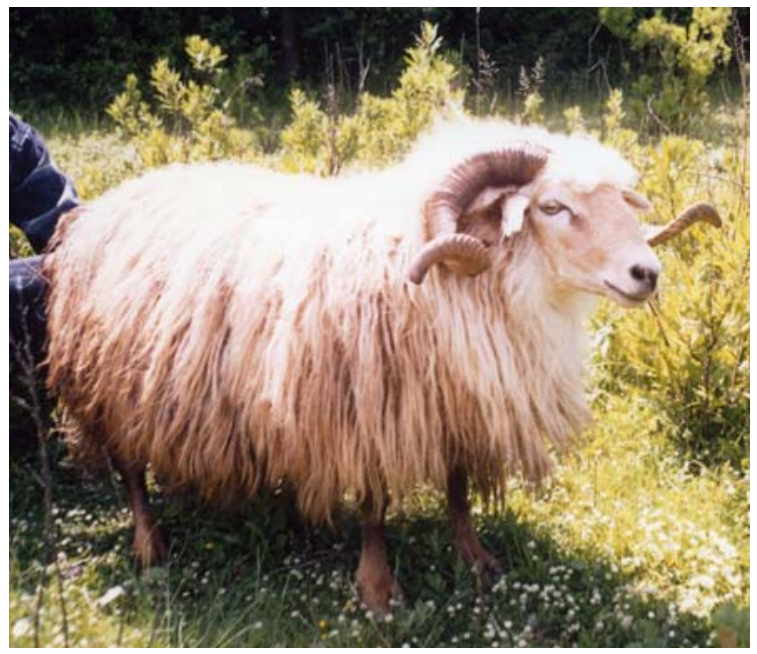

The actual structure of the farms' size according to the number of animals and the wool production is shown in Tab. 3 .

Table 3

The farm structure based on the number of ewes and wool production

\begin{tabular}{lccc}
\hline \hline Item & $\begin{array}{c}\text { Number of } \\
\text { farms }\end{array}$ & $\%$ & $\begin{array}{c}\text { Wool production } \\
\text { /family/year (kg) }\end{array}$ \\
\hline Number of sheep & 240537 & 65.1 & - \\
With $1-10$ ewes & 44956 & 12.2 & $<35$ \\
$11-30$ “ & 58258 & 15.8 & $36-100$ \\
$31-50$ “ & 17895 & 4.8 & $101-170$ \\
$51-100$ “ & 4566 & 1.2 & $171-350$ \\
$101-200$ “ & 2491 & 0.7 & $351-700$ \\
More than 201 “ & 786 & 0.2 & $>700$ \\
\hline Total & 369489 & 100 & \\
\hline \hline
\end{tabular}

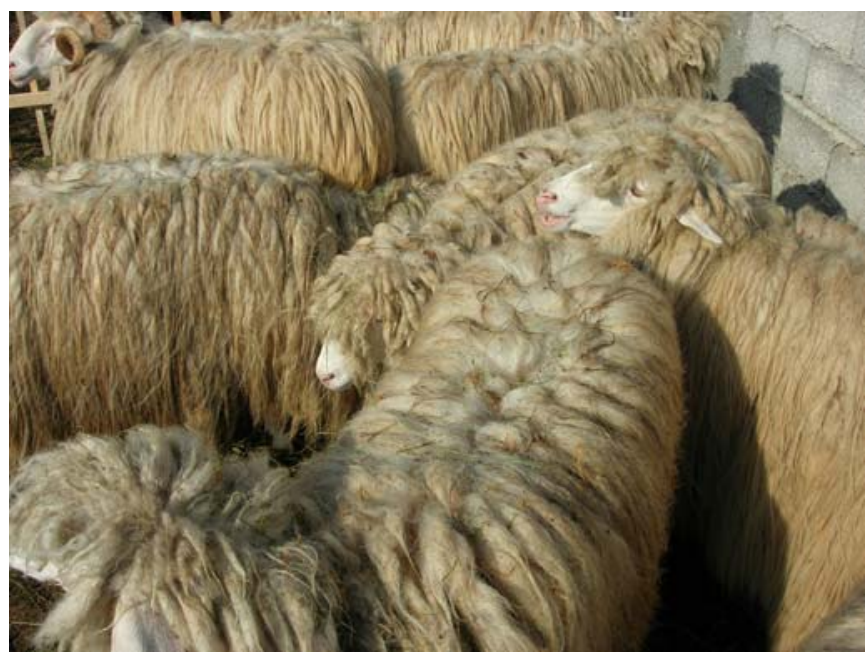

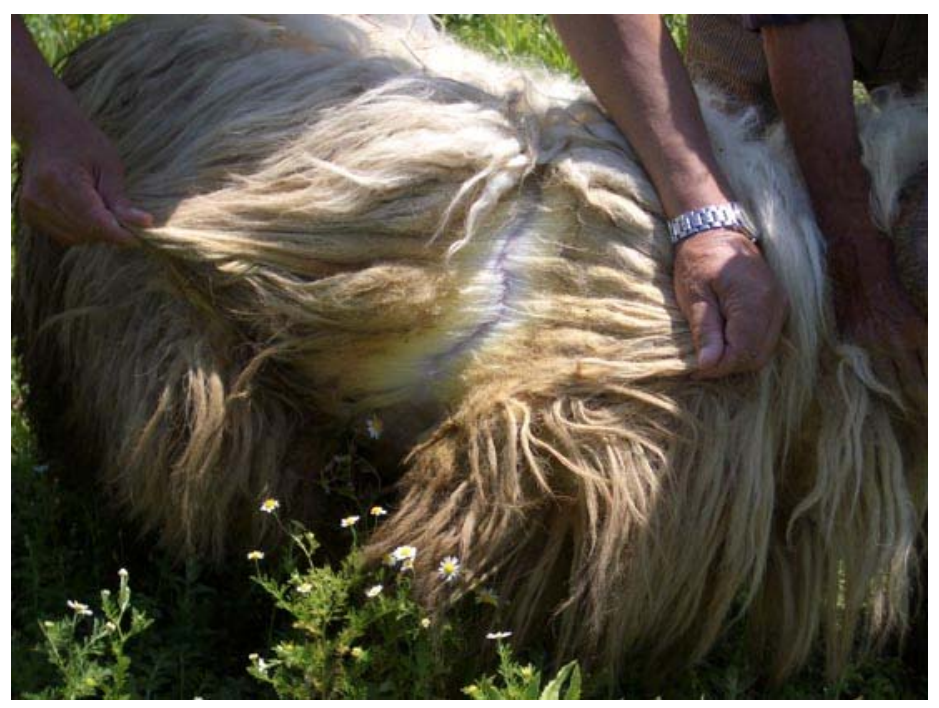


The characteristics of wool production for different local breeds and crossbreeds are shown in Table 4.

According to the Statistical data of MoAFCP, the production of coarse type wool, in 2008, is about $57 \%$ and $43 \%$ of the total wool production is the wool of thin / half thin type (Tab. 5).
Most of the Albanian wool is sold for export very cheaply, direct after shearing (not graded, not washed)- some is simply incinerated. The farmers get a smaller part of their own wool carded. Afterwards it is hand spun and used for weaving or knitting. Most of it is rather coarse and is used for kelims and carpets. The finer wool is used for knitting.

Table 4

Characteristic of wool

\begin{tabular}{lccccl}
\hline \hline Breed & \multicolumn{5}{c}{ Characteristic of wool production* } \\
& $\begin{array}{c}\text { Yield } \\
(\mathrm{kg})\end{array}$ & $\begin{array}{c}\text { Wool's length } \\
(\mathrm{cm})\end{array}$ & $\begin{array}{c}\text { Diameter of fibre } \\
(\mu)\end{array}$ & $\begin{array}{c}\text { Uniformity of wool } \\
(\%)\end{array}$ & Type \\
\hline Rrecka & 1.2 & $16-17$ & $40-44$ & 40 & Coarse \\
Ruda & 1.6 & $12-14$ & $30-33$ & 26 & Half thin \\
Bardhoka & 2.4 & $20-22$ & $50-55$ & 32 & Coarse \\
Shkodrane & 2.8 & $35-45$ & $70-75$ & 50 & Coarse \\
Baca & 2.5 & $25-30$ & $50-55$ & 35 & Coarse \\
Syka e Matit & 1.2 & $13-15$ & $42-45$ & 35 & Coarse \\
Lara e Polisit & 2.2 & $15-18$ & $40-45$ & 38 & Coarse \\
Tsygai crosses & 2.5 & $6-10$ & $25-30$ & 25 & Half thin \\
Merino crosses & 3.8 & $5-8$ & $20-25$ & 15 & Thin \\
\hline \hline
\end{tabular}

*Estimation data

Table 5

The type of wool

\begin{tabular}{lccc}
\hline \hline Type of wool & $\begin{array}{c}\text { Quantity } \\
\text { (tons })\end{array}$ & $\begin{array}{c}\text { Thinness } \\
(\mu)\end{array}$ & $\begin{array}{c}\text { Length } \\
(\mathrm{cm})\end{array}$ \\
\hline Thin wool (Merinos and their crosses) & 600 & $20-25$ & $5-8$ \\
Half thin wool (Ruda. Tsigaia and their crosses) & 1030 & $25-33$ & $6-14$ \\
Coarse wool (native breeds) & 2170 & $35-50$ & $12-40$ \\
\hline \hline
\end{tabular}

\section{WOOL PROCESSING AND MARKETING}

Four years ago a survey in the same districts in the hilly and mountainous areas of Albania, where most of the sheep population was found, with the support of IFAD - Albanian representative and Mountain Areas Financial Fund (MAFF) - Albania, was carried out (Arbirk, M. Danea, 2004). The main conclusions of this survey are as follows:

\section{a) Wool processing enterprises}

In all the regions wool processing enterprises were founded e.g. for carding, dyeing, kelim weav- ing, knotted carpets, hand spinning, one spinning mill (only), hand-knitting, tailoring and some home industries for preparing weddings.

Only in the Kukes region (the Northe East of Albania) a felt maker was met and another heard of. Felting is a dwindling industry, which is traditionally carried out by men producing felt hats.

In all the regions there are possibilities to encourage development in the wool processing industry, especially to support development of felting and other manual processing, like knitting machines, production of more types of clothes, etc.

The owners of carding and spinning enterprises were knowledgeable and skilled. They had difficult business condition, with a small market 
for their business. Often they did not even work every day.

\section{b) Traditional and potential market for wool products}

Only a small and decreasing market for traditional wool products, such as traditional Albanian hats, kelims and knotted carpets, exists.

A local market in the mountain regions and in the bigger towns for selling wool products hardly exists. The wool is expect for carding, mostly handled and used by the sheep owners themselves.

It is a realistic idea to build up a market for modern wool production taking place in the districts as small or medium scale enterprises and home production, then selling the products from specialized shops in the bigger towns, and espe-
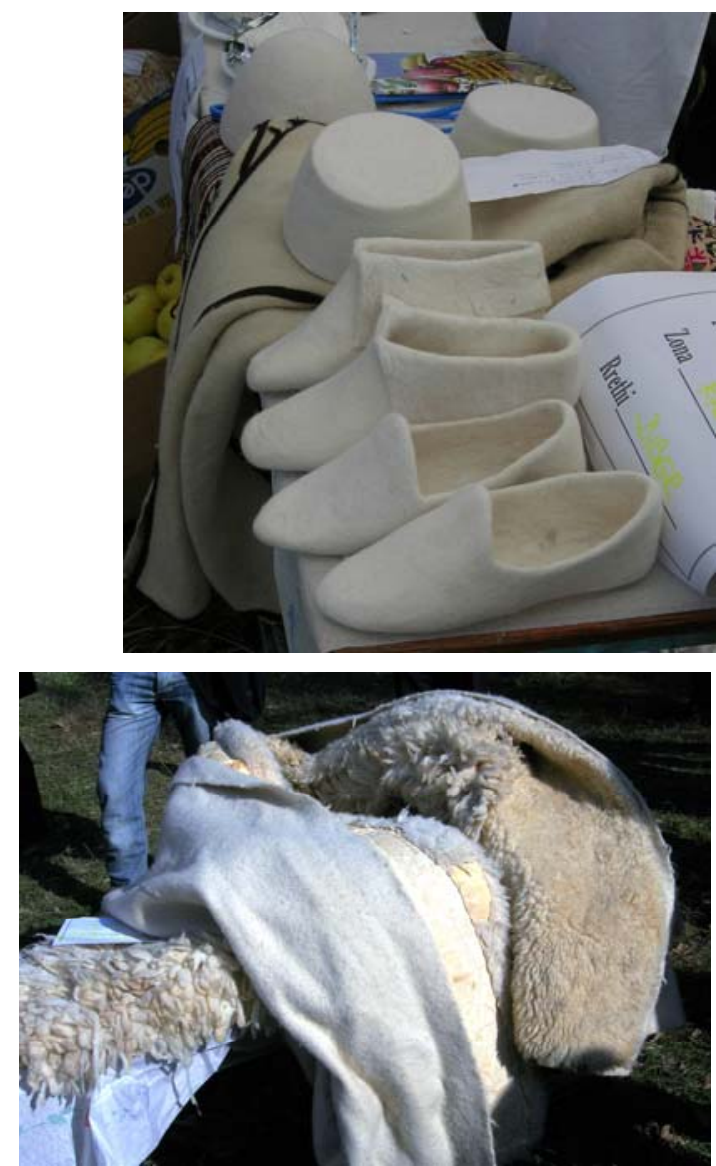

\section{c) The local production potential}

Everywhere there is a tradition of small enterprises and homer production in carding, dyeing, hand spinning, weaving and knitting the wool. The cially for the bigger enterprises, to end up with export .

It is necessary to support all the initiatives for development of smaller enterprises and home production such as:

- modern design in felt clothing and accessories, other felt things for homes, including felting of kitted wool material,

- knitting yarn, knitted clothes and knitted material,

- modern design of kelims and carpets, bed covers and rugs, wool duvets and pillows. And development of bigger enterprises for production of:

- wool mattresses,

- industrial felt, including the use for insulating purposes.
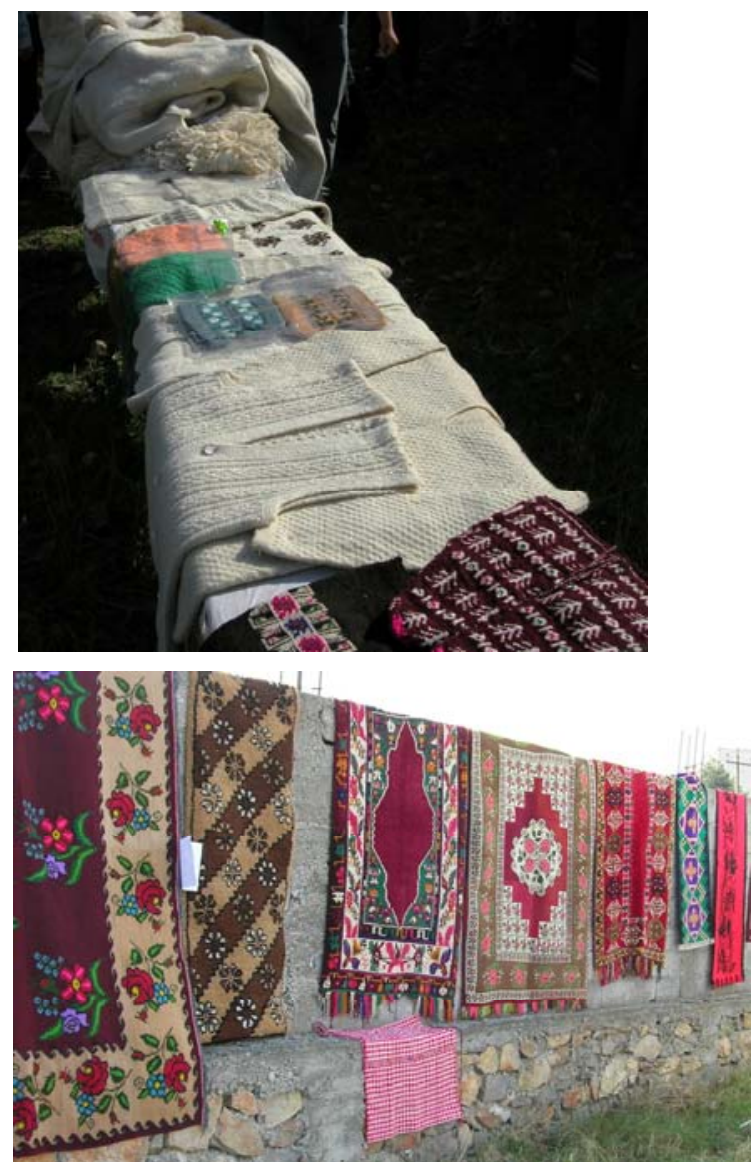

elder generation knows how to handle the wool, but it is a dwindling tradition.

The number of unemployed young women is large. They have a big interest for learning a trade and start in production. 
The potential of progressive and development - oriented women, who want to start their own businesses as entrepreneurs and employ young women, was noted. The women want education, equality and independence.

In accordance with the quality of the wool, there is a big variety of end-products, which might possibly be produced. The fine wool can be used to develop clothes and accessories, which are in direct touch with the body, the half fine can be used for knitting dewaters, rugs, plaids slippers etc., and the coarse wool for interior designs like carpets, kelims and also fabrics of different kinds of furniture etc.

\section{CONCLUSION AND RECOMMENDATION}

The wool production in Albania estimates about $1.2 \mathrm{~kg}$ wool/capita/year. The lack of possibilities for processing and marketing are the factors that for farmers this is an undesirable product.

In order to develop wool processing into finished end-products ready for sale there is a need for coordinate efforts in many different aspects of wool production and processing.

Support to SMEs working with wool processing, training of men/women in wool processing, design of product, marketing and bookkeeping should be started as soon as possible.

A Coordinating Unit for development of wool processing and marketing of wool products should be established.

\section{REFERENCES}

[1] Hahne J., Arbik M. (2004): Wool survey in selection districts in the mountainous areas of Albania.

[2] Kume K., Papa L. (2003): “Animal genetic resources in Albania and their conservation and management problems", First International Congress of Livestock, Dairy and Meat Processing Industry and Marketing. Antalya, Turkey.

[3] Kume K. (2006): La production ovine en Albanie. Atelie, 19, pp. 17-18, Mai 2006.

[4] Ministry of Agriculture, Food and Consumer's Protection, Statistical Yearbook, 2003, 2008. 